\title{
BUDOWA MODELU ŁOPATKI TURBINY WYSOKIEGO CIŚNIENIA LOTNICZEGO SILNIKA TURBINOWEGO
}

\author{
Adam Kozakiewicz, Staniseaw Kachel \\ Wojskowa Akademia Techniczna, Wydziat Mechatroniki i Lotnictwa, Warszawa \\ e-mail: adam.kozakiewicz@wat.edu.pl; stanislaw.kachel@wat.edu.pl \\ KATARZYNA KOZAKIEWICZ \\ Engineering Design Center, Warszawa
}

\begin{abstract}
Artykuł poświęcony jest budowie modelu łopatki turbiny wysokiego ciśnienia lotniczego silnika turbinowego. Przedstawiono ideę procesu projektowania łopatki turbiny i w tym obszarze parametrów własnych turbiny, które zawarto w analizie charakterystyk turbin. Przedstawiono charakterystyki dotyczące zmian głównych parametrów własnych turbiny, tzn. masowego natężenia przepływu, pracy jednostkowej, sprawności, obciążenia czy rozprężu turbiny od parametrów eksploatacyjnych. Przeanalizowano proces tworzenia modelu łopatki w oparciu o inżynierię odwrotną i parametryzację modelu dla potrzeb poniższej pracy. Algorytm tworzenia modelu parametrycznego został zbudowany w języku GRIP dla systemu Siemens NX. Zawarto najważniejsze zalety modelu parametrycznego wraz z matematycznym równoważnikiem wyboru wariantu procesu modelowania obiektu wirtualnego. Przedstawiono efekt budowy modelu w postaci wydruku łopatki w 3D. Uzyskany model będzie podstawą dalszych badań w zakresie charakterystykach aerodynamicznych dotyczącym pojedynczej łopatki, jak również palisady.
\end{abstract}

Stowa kluczowe: silnik turbinowy, turbina gazowa, inżynieria odwrotna, model parametryczny

\section{Wstęp}

W kanałach palisad turbin (rys. 1) mamy do czynienia z procesem rozprężania strumienia spalin wraz z opływem, któremu towarzyszy zmiana pędu następstwem tego jest powstanie siły na palisadzie. Proces zachodzący w turbinie może być rozpatrywany z punktu przekształcenia energii potencjalnej strumienia spalin wypływającego z komory spalania na pracę mechaniczną wirnika oraz zagadnienia opływu łopatek ze skręceniem, czemu towarzyszy powstanie sił i strat energii kinetycznej.

Energia potencjalna strumienia na wejściu do turbiny jest funkcją parametrów strumienia na wyjściu z komory spalania, tzn. ciśnienia spiętrzenia $p_{3}^{*} \mathrm{i}$ temperatury spiętrzenia $T_{3}^{*}$. To przekłada się na moc turbiny, r-nie (1.1). Dodatkowo moc uzyskiwana w turbinie zależna jest od parametrów własnych turbiny, tzn. współczynnika rozprężu na turbinie $\pi_{T}^{*}$ i jej sprawności $\eta_{T}^{*}$

$$
P_{T}=\dot{m}^{\prime} l_{T} \quad l_{T}=f\left(T_{3}^{*}, \pi_{T}^{*}, \eta_{T}^{*}\right)
$$

gdzie: $\dot{m}^{\prime}$ - masowe natężenie strumienia spalin, $l_{T}$ - praca jednostkowa turbiny (praca techniczna), $\pi_{T}^{*}=p_{3}^{*} / p_{4}^{*}$ - rozpręż na turbinie, $\eta_{T}^{*}$ - sprawność efektywna turbiny.

Celem uzyskania większej mocy turbiny dąży się do zwiększenia pierwszej grupy parametrów związanych ze strumieniem na wejściu. Ciśnienie $p_{3}^{*}$ jest funkcją sprężu silnika i strat w komorze spalania. W przypadku parametru $T_{3}^{*}$ obecny trend przy projektowaniu lotniczych zespołów napędowych do samolotów bojowych prowadzi do zwiększenia temperatury przed turbiną wysokiego ciśnienia (rys. 2) [2], [3], [11]. Daje to możliwość wzrostu pracy jednostkowej turbiny. 


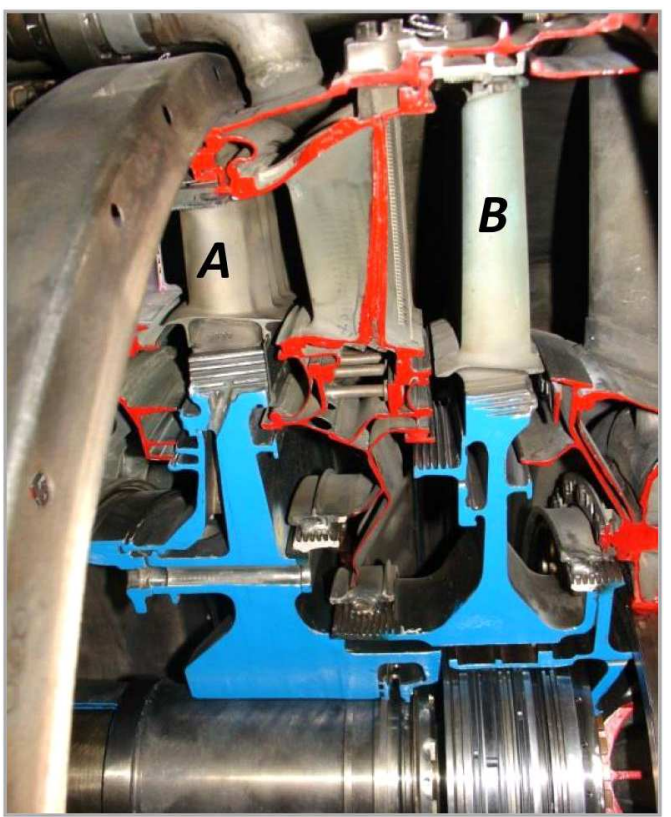

Rys. 1. Zespół turbiny dwuprzepływowego turbinowego silnika odrzutowego RD-33; A - wieniec wirnikowy turbiny wysokiego ciśnienia, B - wieniec wirnikowy turbiny niskiego ciśnienia [fot. A. Kozakiewicz]

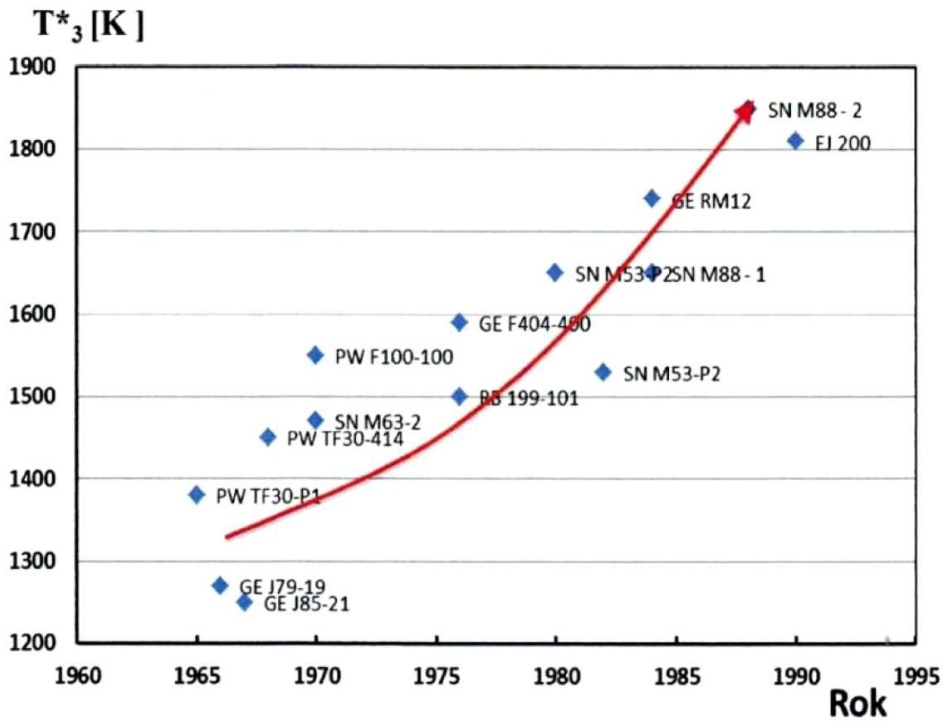

Rys. 2. Zmiana temperatury przed turbiną silników samolotów wojskowych [12]

Przykład zmiany obciążenia turbiny w zależności od zmiany temperatury wlotowej do turbiny na przestrzeni lat jest pokazany na wykresie na rys. 3. Wzrost ten jest efektem zwiększenia sprawności, redukcji strat związanych z przeciekami strumienia, rozwojem inżynierii materiałowej oraz zwiększeniem efektywności chłodzenia.

Parametry własne turbiny: masowe natężenie przepływu spalin $\dot{m}^{\prime}$ i współczynnik rozprężu w turbinie $\pi_{T}^{*}$ w istotny sposób zależne są od geometrii palisady turbiny, która związana jest z układem profili łopatek. Projektowanie łopatki turbiny jest procesem złożonym oraz iteracyjnym. Został on przedstawiony na rys. 4. Projektowanie obejmuje zagadnienia z obszaru analizy przepływowej wstepnej (2D Channel Flow Analysis) i całego obiektu (3D Channel Flow Analysis). Ważną częścią całego projektu jest budowa geometrii łopatki, w tym geometrii profili 


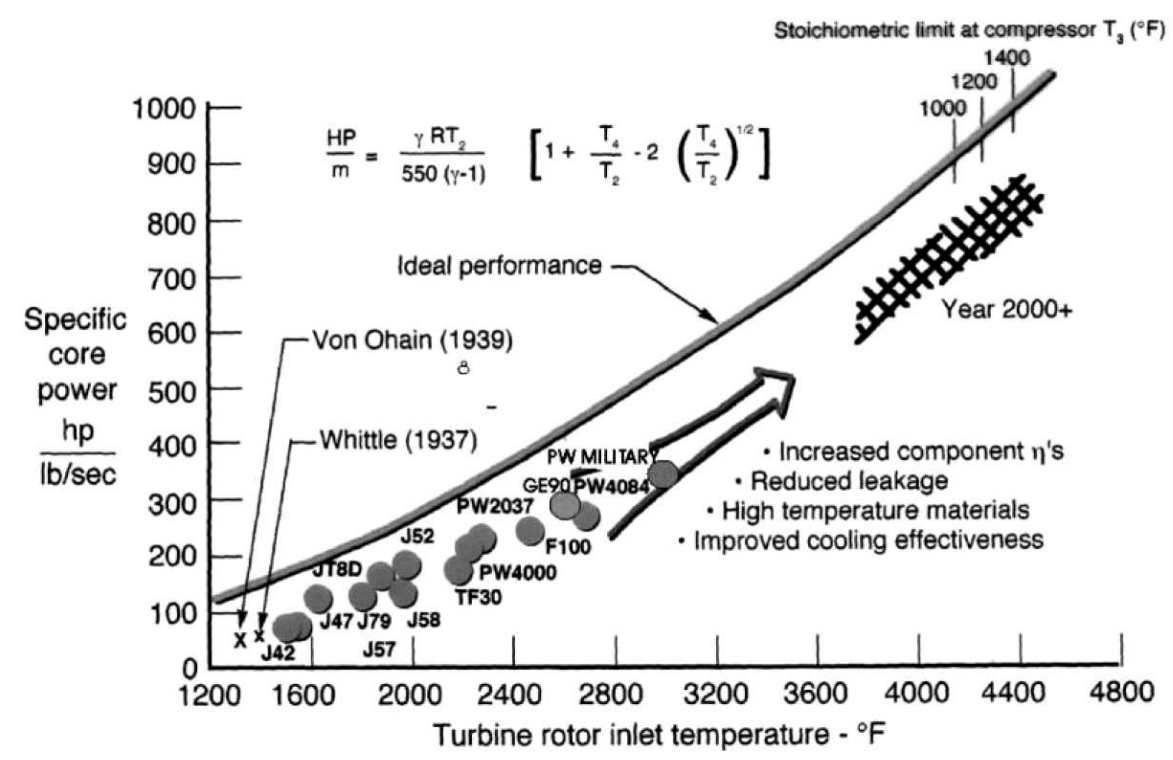

Rys. 3. Wzrost pracy jednostkowej turbiny w funkcji temperatury przed turbiną [4]

Preliminary

Design

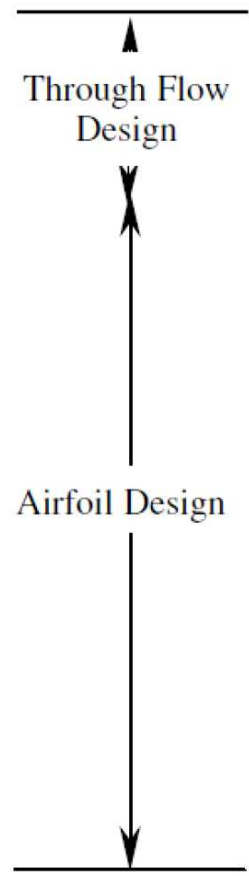

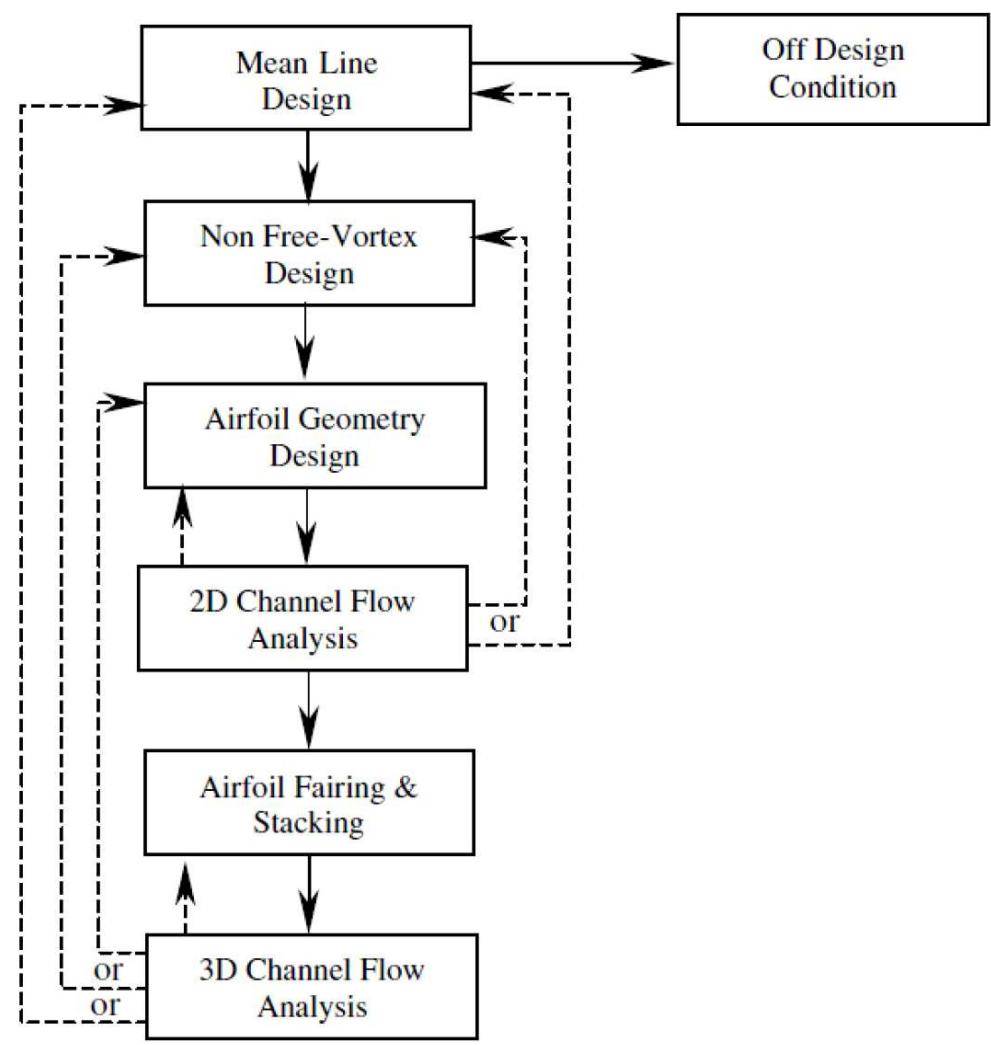

Rys. 4. Proces projektowania łopatki turbiny [13]

łopatki (Airfoil Geometry Design). Każdy z tych etapów jest ważny z uwagi na poprawność pracy całego układu, którego miernikiem jest sprawność. W tym artykule autorzy skupili się na zagadnieniu budowy geometrii łopatki w oparciu o istniejące rozwiązanie. Projekt geometryczny pióra łopatki musi zapewnić odpowiednią przepustowość turbiny przy odpowiednim stopniu rozprężania $\pi_{T}^{*}$. Ta grupa parametrów z uwagi na istotę osiągów turbiny przedstawiana jest w postaci charakterystyk turbin, które zostaną zaprezentowane w kolejnym punkcie pracy. 


\section{Charakterystyki turbin}

Warunki pracy turbiny lotniczego silnika turbinowego zmieniają się istotnie wraz ze zmianą prędkości obrotowej wirnika oraz parametrów lotu (wysokości i prędkości). Przy pracy turbiny na zakresach pozaobliczeniowych zmienia się charakter opływu jej palisad, a wraz z nimi parametrów strumienia wzdłuż kanału przepływowego, w tym wartości masowego natężenia przepływu strumienia spalin $\dot{m}^{\prime}$, sprawności efektywnej $\eta_{T}^{*}$, pracy jednostkowej turbiny $l_{T}$ oraz stopnia rozprężania $\pi_{T}^{*}$

$$
\dot{m}^{\prime}, l_{T}, \eta_{T}^{*}=f\left(\pi_{T}^{*}, n, c_{a} / u\right)
$$

Najczęściej spotykanymi charakterystykami turbin są zależności wyżej wymienionych parametrów turbiny (2.1) od parametrów określających zakres jej pracy. Są one istotne podczas doboru zespołu turbiny do silnika, jak również w procesie sterowania lotniczym silnikiem turbinowym. Wpływa to na wybór zakresów eksploatacyjnych pracy silnika. Zakresy pracy turbiny, w tym zakres eksploatacyjny, określa się poprzez wartość prędkości obrotowej, która również definiuje charakterystyki aerodynamiczne palisad turbiny.

Turbina jest projektowana na określony współczynnik rozprężania $\pi_{T}^{*}$, co w powiązaniu z określonymi prędkościami strumienia spalin na wejściu i wyjściu musi zgodnie z równaniem ciągłości (2.2) odpowiadać zmianom przekrojów wejścia i wyjścia

$$
\dot{m}^{\prime}=j \frac{p^{*}}{\sqrt{T^{*}}} q(\lambda) A
$$

gdzie: $j=f\left(k^{\prime}, R^{\prime}\right)$ - stała zależna od własności spalin, $p^{*}$ - ciśnienie spiętrzenia, $T^{*}$ - temperatura spiętrzenia, $q(\lambda)$ - względna gęstość strumienia, $A$ - pole przekroju.

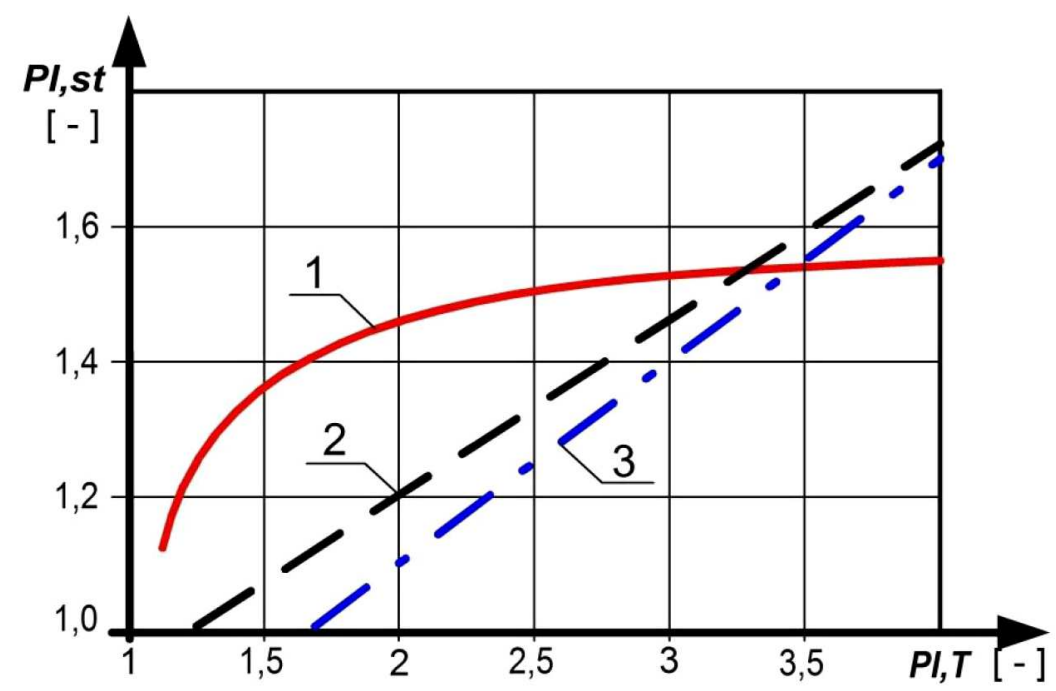

Rys. 5. Rozkład zmian stopnia rozprężania w układzie turbiny trójstopniowej: $P I, s t=\pi_{T, s t}^{*}-$ rozpręż na pojedynczym stopniu turbiny, $P I, T=\pi_{T}^{*}-$ całkowity rozpręż $\mathrm{w}$ turbinie, $1-\pi_{T, s t}^{*}$ dla pierwszego stopnia, $2-\pi_{T, s t}^{*}$ dla drugiego stopnia, $3-\pi_{T, s t}^{*}$ dla trzeciego stopnia [10]

Praca turbiny poza zakresami obliczeniowymi wywołuje problemy ze statecznością pracy całego silnika. Przypadek pracy turbiny wielostopniowej na zakresie poniżej wartości obliczeniowej może prowadzić do procesu sprężania w jej ostatnich stopniach, co jest niedopuszczalne. Przykładowy rozkład zmian współczynnika rozprężania w układzie turbiny trójstopniowej w poszczególnych stopniach przedstawiony jest na rys. 5 . W układach wielostopniowych turbina jest projektowana według zasady, że w kolejnych stopniach współczynnik rozprężania jest większy 
niż w stopniu poprzedzającym. Przyjmuje się, że pierwszy stopień turbiny pracuje na zakresach $\pi_{T, 1}^{*}>1,7$.

Istotną charakterystyką silnika turbinowego oraz zespołu turbiny jest charakterystyka obrotowa, jak wcześniej wspomniano. Tego typu charakterystykę dwustopniowej turbiny niskiego ciśnienia dwuprzepływowego turbinowego silnika odrzutowego współczynnika rozprężania $\pi_{T, N C}^{*}$ i izoklin sprawności $\eta_{T}^{*}$ w funkcji względnej kryterialnej prędkości obrotowej $n_{k r, w}$ przedstawiono na rys. 6. Na charakterystyce zaznaczono obszar eksploatacyjny pracy turbiny (obszar pomiędzy krzywymi 1 i 2) oraz punkt obliczeniowy. Stosowanie kryterium wysokiej sprawności turbiny $\left(\eta_{T}^{*}>91 \%\right)$ wymusza prace przy dużych wartościach rozprężu $\pi_{T, N C}^{*}$. Prowadzi to do dość wąskiego przedziału eksploatacyjnego prędkości obrotowych silnika $\left(n_{k r, w}>80 \%\right)$ i turbiny dla analizowanej charakterystyki. Obszar spełniający to kryterium pracy silnika turbinowego dla $\pi_{T, N C}^{*}$ zawarty jest w przedziale powyżej wartości 3,0 .

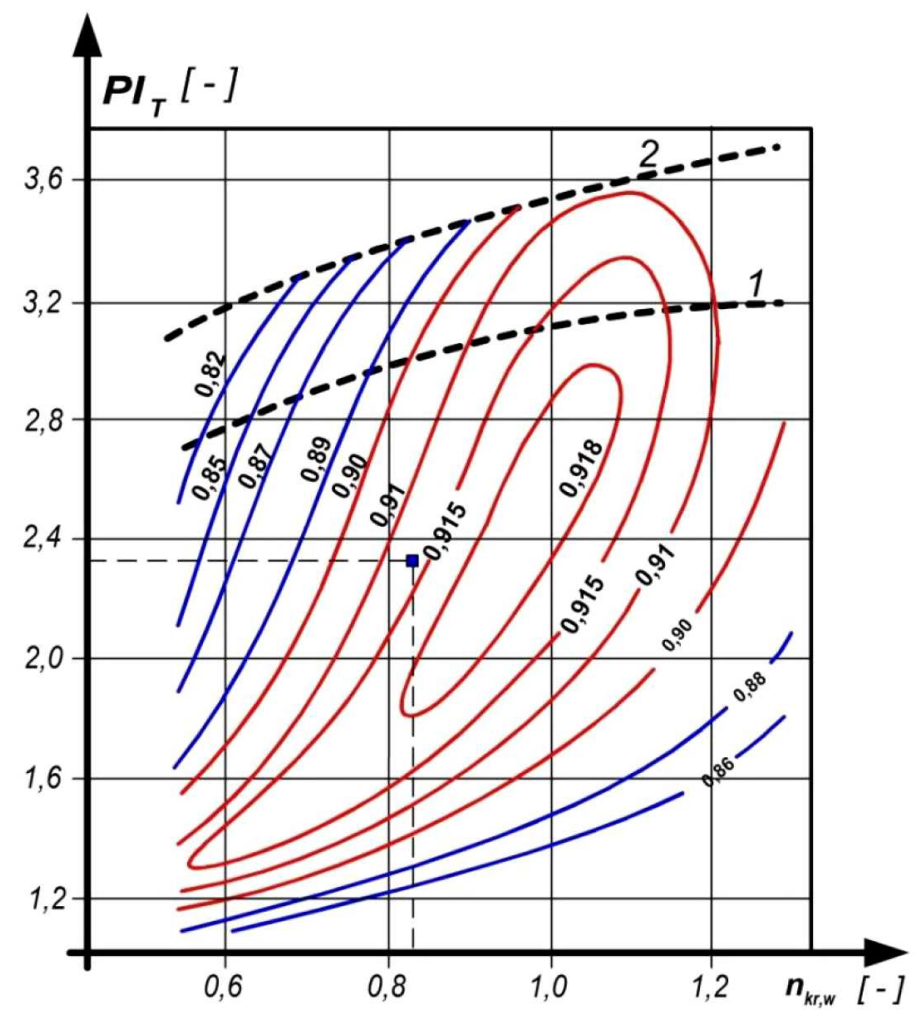

Rys. 6. Charakterystyka dwustopniowej turbiny niskiego ciśnienia dwuprzepływowego turbinowego silnika odrzutowego: 1 - dolna granica pracy zakresów ustalonych turbiny, 2 - górna granica pracy turbiny, $n_{k r, w}$ - względna kryterialna prędkość turbiny, - - punkt obliczeniowy [10]

Duża wartość $\pi_{T, N C}^{*}$ przekłada się na przepustowość przepływu spalin przez turbinę. Daje to maksymalną wartość masowego kryterialnego natężenia przepływu $\dot{m}_{k r}$ (rys. 7). Istotną cechą turbin jest, że wraz ze wzrostem rozprężu w turbinie $\pi_{T}^{*}$ następuje wzrost prędkości przepływu, co pociąga wzrost względnej gęstości strumienia $q(\lambda)$. Odpowiednio wzrasta wartość $\dot{m}^{\prime} \sqrt{T^{*}} / p^{*}$. Wzrost ten następuję do momentu osiągnięcia prędkości dźwięku w kanale międzyłopatkowym turbiny, po czym dalszy wzrost $\pi_{T}^{*}$ nie daje wzrostu $q(\lambda)$ i nie ulega zmianie $\dot{m}_{k r}$. Zmiana prędkości kryterialnej $n_{k r, w} \mathrm{w}$ tym zakresie $\pi_{T}^{*} \mathrm{w}$ małym stopniu zmienia masowe kryterialne natężenie przepływu.

Kolejny obszar charakterystyk dotyczy stopnia obciążenia turbiny i jest zawarty w szeregu opracowaniach. Jedna z bardziej pełnych analiz charakterystyk obciążenia stopnia turbiny w funkcji sprawności i współczynnika przepływu (przedstawiona na rys. 9) zawarta jest w pracy [6]. Charakterystyka obrazuje istotę problemu związanego z połączeniem parametrów ter- 


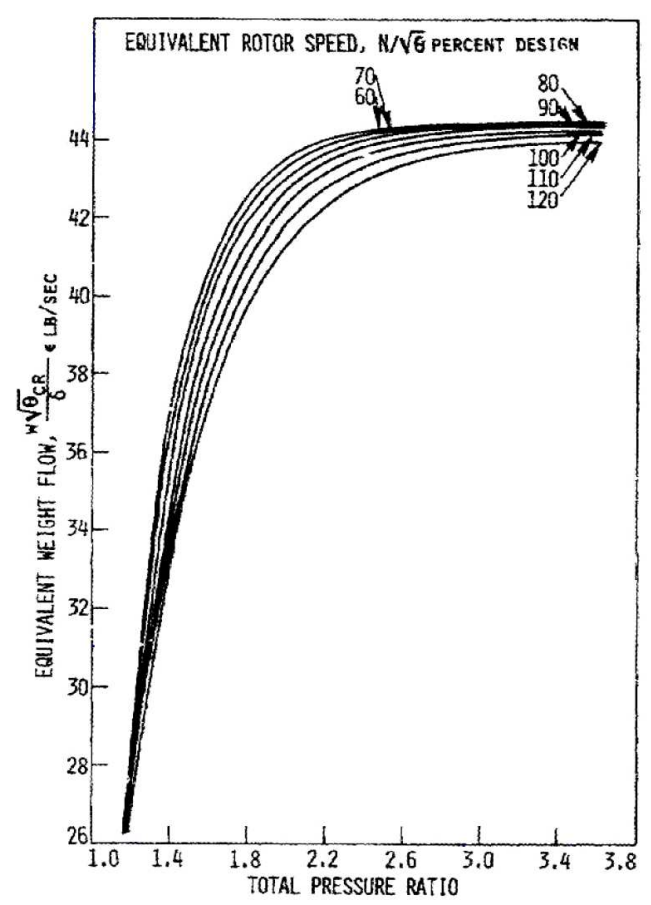

Rys. 7. Zmiana kryterialnego masowego natężenia przepływu $\dot{m}_{k r} \mathrm{w}$ dwustopniowej turbinie w funkcji prędkości kryterialnej i stopnia rozprężu [1]

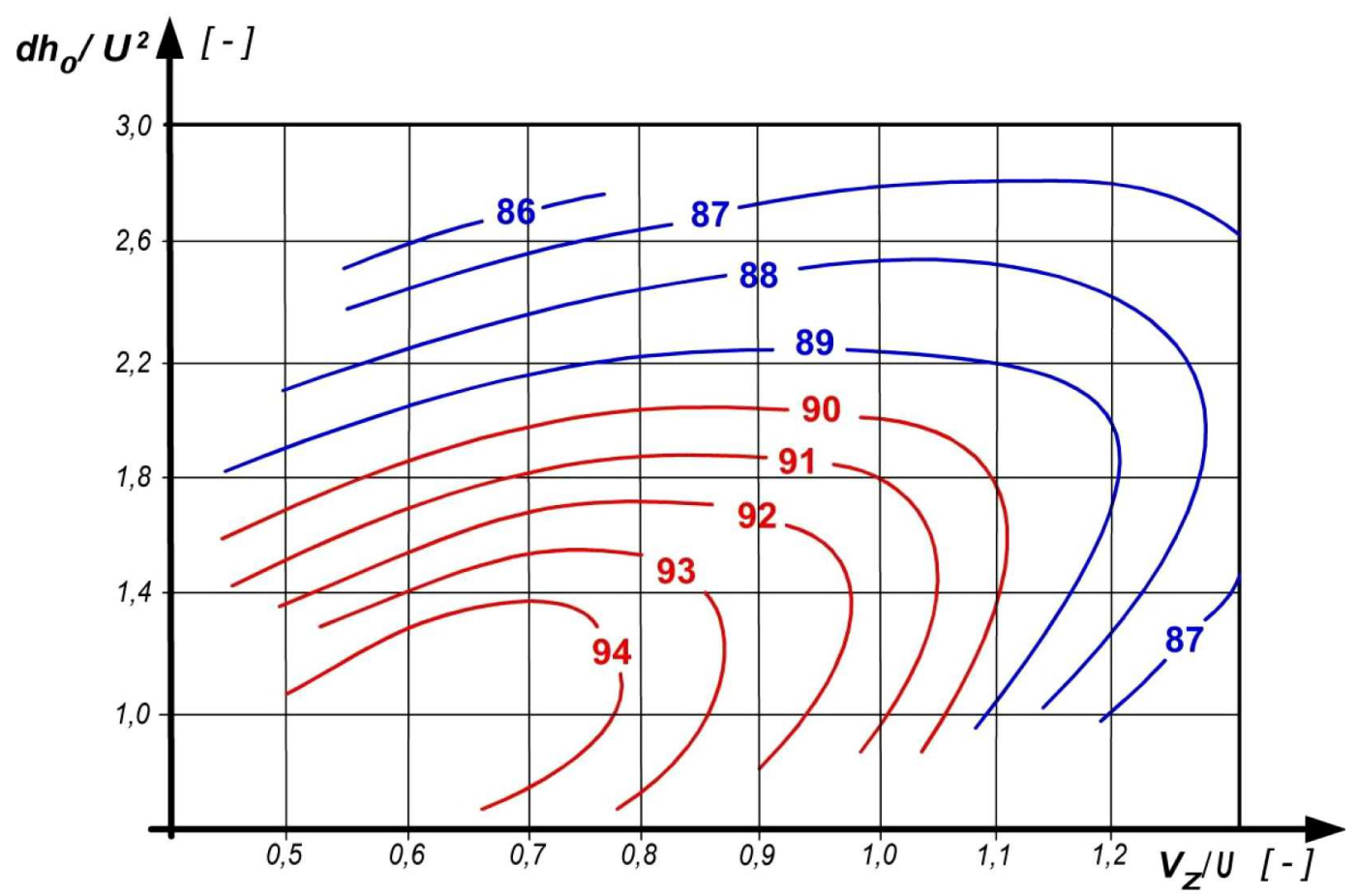

Rys. 8. Charakterystyka obciążenia stopnia turbiny w funkcji sprawności i współczynnika przepływu: $\Delta h_{0} / U^{2}$ - współczynnik obciążenia stopnia turbiny (spadek entalpii w turbinie do kwadratu prędkości obwodowej), $V_{z} / U$ - współczynnik przepływu (składowa osiowa prędkości przepływu do prędkości obwodowej) [6] 
modynamicznych z kinematycznymi strumienia z uwagi na osiagi turbiny, co wyraża się przez współczynnik obciążenia turbiny $\Delta h_{0} / U^{2}$. Wynika stąd wniosek, że wysoką sprawność układu, powyżej $90 \%$, można uzyskać jedynie przy niższych wartościach $\Delta h_{0} / U^{2}$ i ograniczonym współczynniku przepływu $V_{z} / U<1,1$. Zwiększając stopień rozprężania, zwiększa się wartość spadku entalpii $\Delta h_{0}$, co przekłada się na wzrost obciążenia, następstwem czego jest uzyskanie większych przyspieszeń strumienia w palisadzie z przepływem strumienia w zakresie naddźwiękowym. Daje to również wzrost strat związanych ze stratami falowymi i tarciem [5]. Celem ograniczenia strat, które przekładają się na sprawność turbiny, należy je projektować w układach wielostopniowych. Przykładowe dane dotyczące rozbieżności wartości sprawności turbiny, zakładanych (projektowanych) i uzyskanych w rzeczywistości, przedstawione są na wykresie na rys. 9.

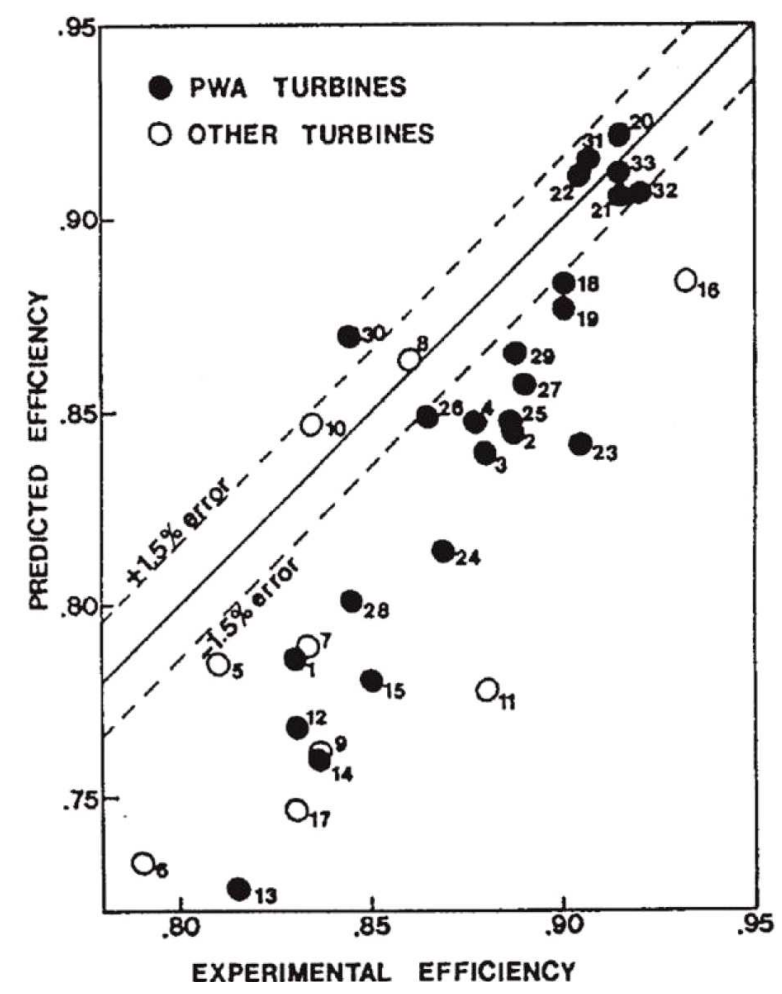

Rys. 9. Porównanie sprawności eksperymentalnych z oczekiwanymi turbin [14]

Przeprowadzona analiza jednoznacznie dowodzi, że głównymi ograniczeniami wynikającymi z charakterystyk dla stopnia turbiny są:

- wielkość masowego natężenia przepływu spalin $\dot{m}^{\prime}$,

- temperatura spalin $T_{3}^{*}$,

- stopień rozprężu spalin $\pi_{T}^{*}$.

Istotnym parametrem wpływającym na wytrzymałość termiczną elementów turbiny (wieńca dyszowego i wirnikowego) temperatury spalin $T_{3}^{*}$ (rys. 2). Drugim parametrem związanym z wytrzymałością jest prędkość obwodowa $U$, która bezpośrednio związana jest z prędkością obrotową wirnika. Wpływa ona na wielkość uzyskiwanych naprężeń w elementach wirujących turbiny.

Charakterystyka obciążeniowa przedstawiona na rys. 8, może być modyfikowana i rozszerzona o inne parametry, jak np.: prędkość kryterialną $n_{k}$ czy rozpręż na turbinie $\pi_{T}^{*}$. Wykorzystanie rodziny charakterystyk umożliwia bardziej dokładne określenie punktu optymalnego, np. obciążenie-sprawność-zapotrzebowanie na wydatek spalin. Umożliwia także, przy żądanym kryterium, bardziej dokładne ustalenie optymalnego punktu pracy, np. dla wybranego obciąże- 
nia można dostroić prędkość wirnika ze sprawnością i określić wartość lub przedział masowego natężeniem przepływu.

Zmodyfikowana charakterystyka obciążeniowa, oprócz masowego natężenia przepływu oraz sprawności, jak na charakterystyce na rys. 8, uzupełniona jest o kryterialną prędkość obrotową i stopień rozprężania. Charakterystyka w bardzo przejrzysty sposób pokazuje złożoność doboru parametrów, dotyczącą maksymalizacji pracy/energii z turbiny.

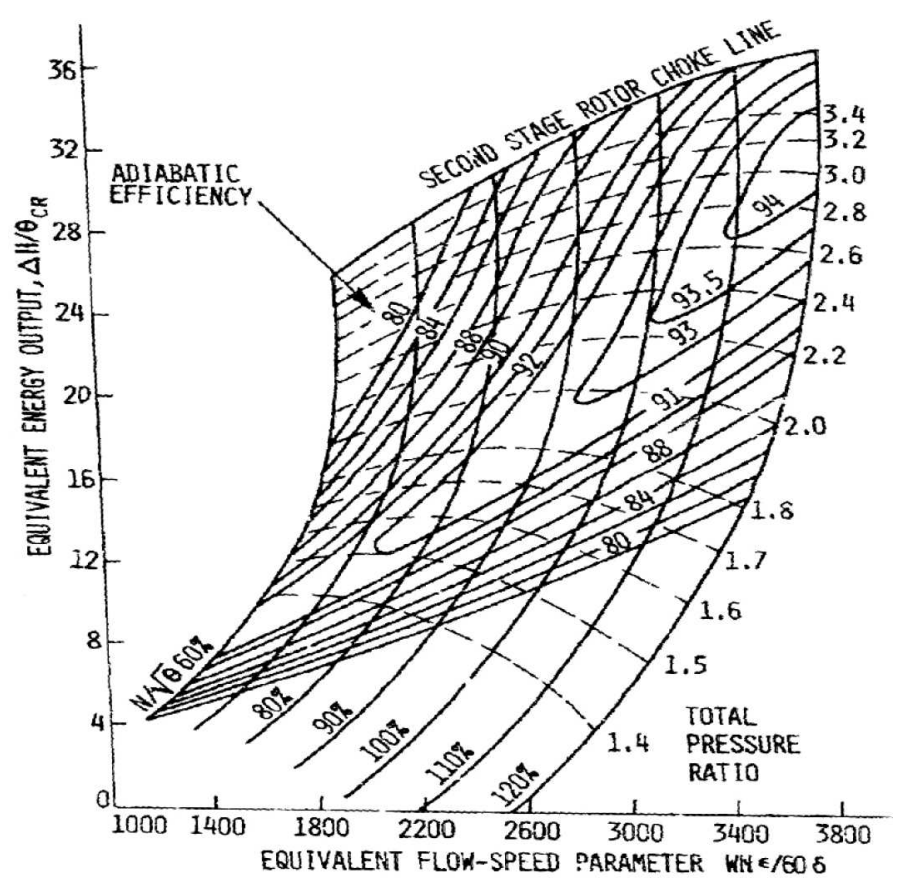

Rys. 10. Charakterystyka obciążenia stopnia turbiny w funkcji sprawności i współczynnika przepływu [1]

Energia uzyskiwana przy dużych prędkościach obrotowych nie zawsze musi wiązać się z wysoką sprawnością oraz dużym stopniem rozprężania. Przykładowo, na zakresie prędkości odpowiadającej wartości $100 \%$ uzyskana sprawność może być niższa niż 93\%. Należy zauważyć, że w przypadku silników lotniczych czas pracy na zakresie maksymalnym jest ograniczony z uwagi na duże obciążenia termiczno-mechaniczne. Obszar wysokich sprawności (powyżej 93\%) jest bardzo mały i związany z bardzo wysokimi parametrami pracy turbiny. Obniżenie sprawności „Zaledwie" o wartość $2 \%$, do obszaru poniżej $91 \%$ sprawności turbiny, daje możliwość doboru parametrów pracy z dużą elastycznością.

\section{Budowa modelu trójwymiarowej łopatki}

Projektowanie lub odtwarzanie elementów składowych silników w systemie CAD/CAM/CAE, które oparte jest o metodę „parametrycznego modelu głównego" prowadzi do wymuszenia zmian sposobu podejścia do procesu projektowania na etapie opisu modelu w zintegrowanym systemie CAD/CAM/CAE. Proces eliminacji błędów pomiarowych, mający wpływ na ustalenie podstawowych parametrów obiektu oparty o algorytm optymalizacji wyboru punktu [15], [16], powoduje skrócenie czasu uzyskania wirtualnego modelu przydatnego do analizy geometrii obiektu. Algorytm tworzenia modelu parametrycznego został zbudowany w języku GRIP. Do najważniejszych zalet modelu parametrycznego należy zaliczyć:

- eliminacja niewygodnych poprawek geometrii, które wydłużają czas tworzenia modelu geometrycznego,

- zmniejszenie liczby zmiennych w procesie ustalania charakterystycznych wielkości, 
- możliwość określenia reguł wnioskowania o zachowaniu pośrednich parametrów,

- ustalenie reguł odtwarzania i modyfikacji pozwalających na zmianę geometrii z zachowaniem parametrów niezmiennych, które zostały narzucone,

- tworzenie elementów składowych modelu geometrycznego, np. pióro lub zamek łopatki (rys. 11), które stanowią podstawę tworzenia elementów struktury obiektu (np. łopatki turbiny) niezbędnych do przeprowadzenia analiz geometryczno-masowych, wytrzymałościowych, przepływowych oraz technologicznych.

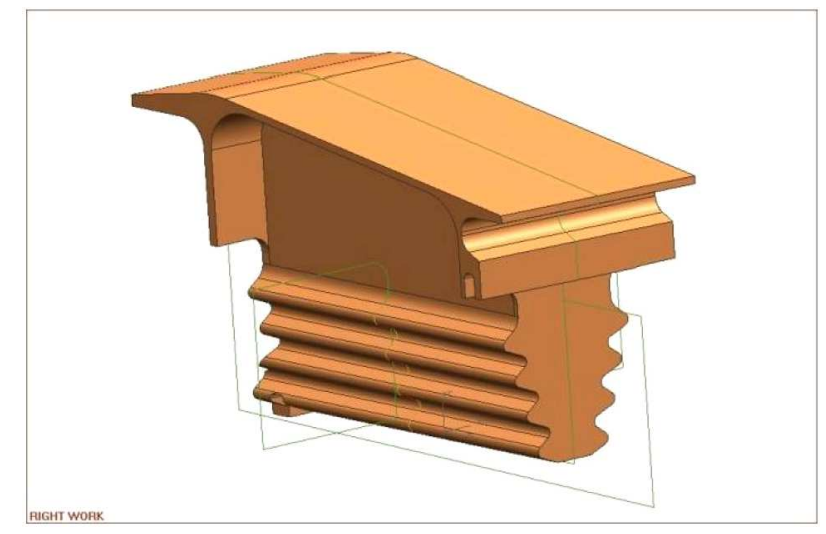

Rys. 11. Element składowy modelu geometrycznego łopatki turbiny - wielotrapezowy zamek łopatki

Dla potrzeb realizowanego zadania naukowego wykorzystano istniejący układ turbiny wysokiego ciśnienia silnika RD-33 (rys. 1). Do zbudowania modelu geometrycznego turbiny wykorzystano metodę inżynierii odwrotnej [7]-[9], [12]. Sformułowanie zadania utworzenia modelu wirtualnego metodą inżynierii odwrotnej wyróżnia się dużą liczbą optymalizowanych zmiennych, głównie o charakterze kombinatorycznym lub kombinatoryczno-cyklicznym [15], [16] nakładanych więzów związanych z ograniczeniami geometrycznymi. Nałożone ograniczenia nie pozwalają na bezpośrednie rozwiązanie bez podziału na wzajemnie powiązany zbiór zadań rozwiązujących poszczególne etapy modelowania. Podział ogólnego zadania, a następnie rozwiązanie wydzielonych podzadań opiera się przede wszystkim na specyficznych właściwościach optymalizowanego wskaźnika jakości odtwarzanego obiektu oraz związkach i występujących ograniczeniach zadania początkowego (wyjściowego). Za obiekt należy w tym przypadku rozumieć badany element (detal), np. łopatkę i jej składowe elementy/części. Istotnym czynnikiem skutecznego rozwiązania wskazanego problemu jest możliwość wydzielenia etapów, tworzenia obiektu wirtualnego, należących do najważniejszej klasy zadań matematycznych.

Matematyczny równoważnik wyboru wariantu procesu modelowania obiektu wirtualnego (z pomiarów współrzędnościowych) stanowi optymalizację wskaźnika jakości opartego o proces pomiarów współrzędnościowych. Zadanie optymalizacji pomiarowej polega na wyznaczeniu charakterystyk zapewniających odpowiedni rozkład dystrybuanty $E(x)$ założonego procesu $A$ modelowania prowadzącego do rozwiązania problemu na bazie wykonanych pomiarów i pomiaru obiektu spełniającego zadanie dla ustalonego wskaźnika jakości $y_{x}(t)$ oraz obiektu spełniającego wektor zadań $y_{x}$

$$
\left\{y_{x}(t), y_{x}\right\}
$$

Są one optymalne z punktu widzenia minimalizacji wskaźnika jakości

$$
F\left(X, \bar{A},\left\{\bar{y}_{x}\right\},\left\{u_{x}(t)\right\}, \bar{E}(x)\right)=\min F\left[X, A,\left\{y_{x}\right\},\left\{u_{x}\left(t_{i}\right)\right\}, E(x)\right]
$$

gdzie: $X=\left(x^{(1)}, x^{(2)}, \ldots, x^{(n)}\right)$ - obiekt optymalizowany (ustalony wektor zadań), $\left\{y_{x}\right\}$ - wektor parametrów dostrajania, $\left\{u_{x}\left(t_{i}\right)\right\}$ - wektorowa funkcja sterowania. 
Minimalizacja funkcjonału obarczona jest następującymi warunkami

$$
A \subset Y \quad E(x) \subset\{1, \ldots, n\} \quad n \geqslant 1
$$

gdzie: $A$ - mierzony obiekt modelowy (spełniający kryteria), $Y$ - zbiór silników.

Formułowanie strategii, która obejmie fizycznie realizowany proces spełniający wykonanie zadań pomiarowych zdefiniowanych w zbiorze $X$ jest następujący

$$
A=\left\{y_{j}\right\} \quad y_{j} \in Y_{D_{(y j)}} \quad j=1, \ldots, n
$$

W przypadku, gdy rozpatrywany jest jeden typ odwzorowanego obiektu, wtedy proces sprowadza się do opisu układu konstrukcyjnego (geometrycznego) i podstawowych charakterystyk elementów projektowanego lub odtwarzanego obiektu. Rozpatrując powyższe założenia w stosunku do łopatki turbinowego silnika odrzutowego (rys. 12a), zagadnienia te można podzielić na dwa etapy. Modelowanie pióra łopatki, gdzie należy uwzględnić kryterium aerodynamiczne, które w rozpatrywanym przypadku jest ściśle związane z geometrycznym kryterium typu $y \in Y_{x}$ oraz zamka łopatki, uwzględniając kryteria geometryczno wytrzymałościowe. Poniżej zamieszczono podprogram realizujący powyższą operację.

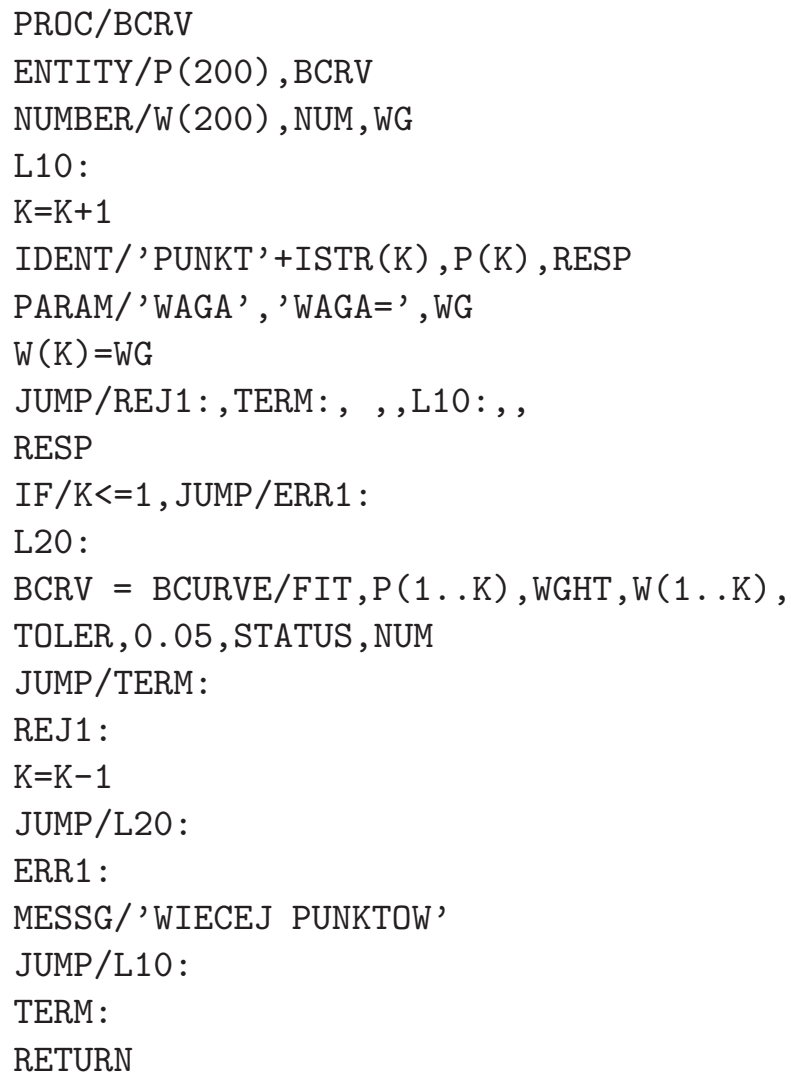

Krzywa określająca kontur profilu (rys. 12) zależy od parametrów globalnych, takich jak kąt natarcia strumienia niezaburzonego oraz kąt zejścia strugi z rozpatrywanego profilu.

W wyniku realizacji programu otrzymamy zbiór punktów odwzorowujący poszukiwaną krzywiznę profili na ściśle zdefiniowanych wysokościach pióra łopatki (rys. 13b).

Budowę geometrycznego wzorca będącego podstawą weryfikacji fizycznych obiektów porównywanych metodac pomiarów oparto na opracowanych własnych algorytmach do systemu Siemens NX. Zastosowanie funkcji splajnowych dało możliwość wykorzystania parametrycznego podejścia do procesu modelowania wirtualnych obiektów. 


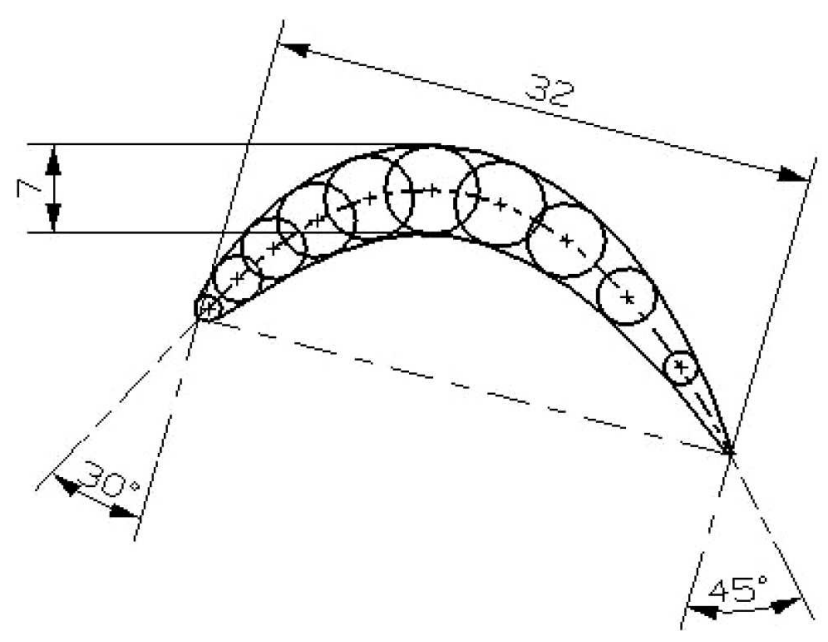

Rys. 12. Przykład konstrukcji profilu aerodynamicznego z uwzględnieniem konstrukcyjnego kata natarcia i kąta spływu

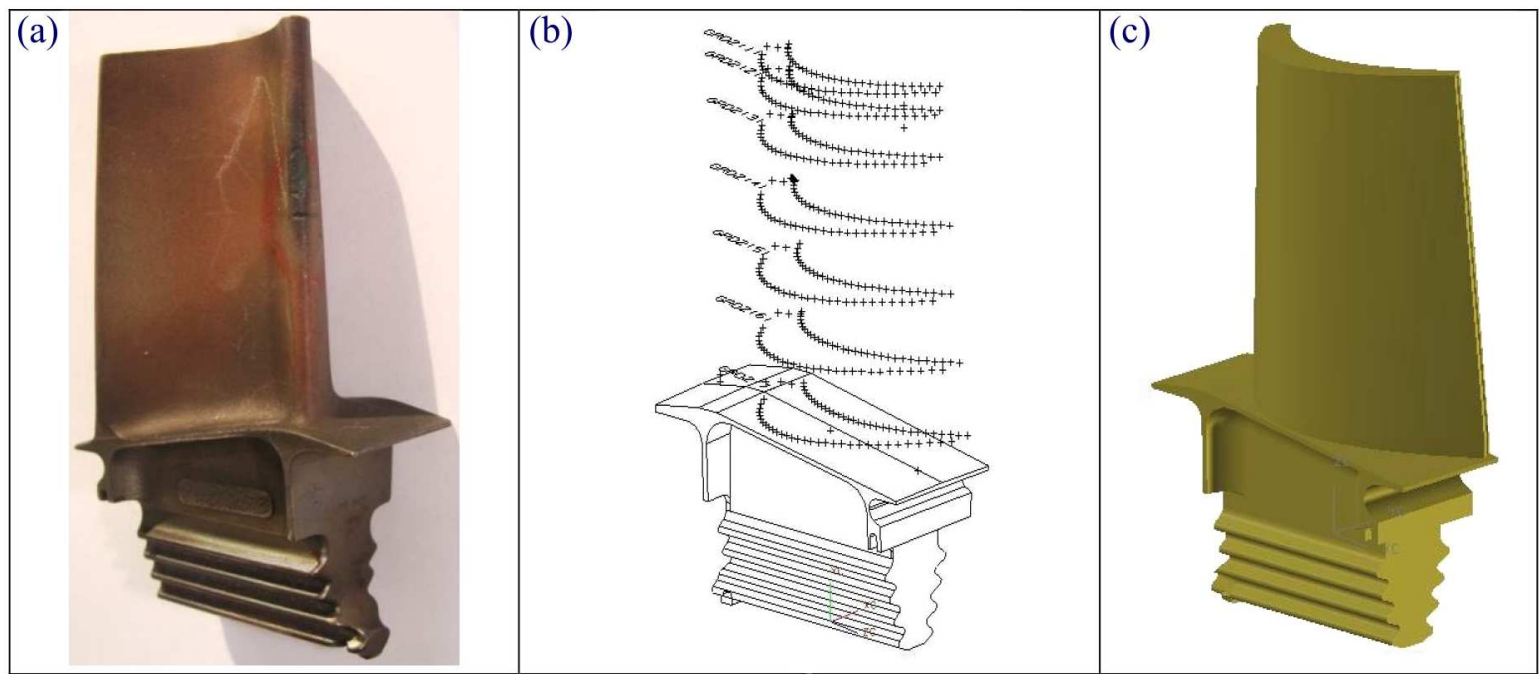

Rys. 13. Wynik poszukiwania punktów odwzorowujących krzywe profili łopatki: (a) łopatka turbiny wysokiego ciśnienia silnika RD-33, (b) profile pióra łopatki z zamkiem, (c) model łopatki

Dowolny punkt $p(t)$ krzywej, znaleziony za pomocą algorytmu de Casteljau, wyraża się wzorem

$$
p(t)=\frac{\sum_{i=0}^{n} w_{i} p_{i} B_{i}^{n}(t)}{\sum_{i=0}^{n} w_{i} B_{i}^{n}(t)}
$$

Powyższy wzór (3.4) może posłużyć jako definicja krzywej wymiernej dla dowolnego ciągu punktów kontrolnych $\mathrm{i}$ wag, $\mathrm{z}$ wyjątkiem wag równych 0 . Jeśli jednak $w_{i}=0$, to punkt $p_{i}$ nie ma wpływu na kształt krzywej. Dlatego czasem zachodzi potrzeba użycia ogólniejszego wzoru

$$
p(t)=\frac{\sum_{i=0, \ldots, n, w_{i} \neq 0} w_{i} p_{i} B_{i}^{n}(t)}{\sum_{i=0}^{n} w_{i} B_{i}^{n}(t)}+\frac{\sum_{i=0, \ldots, n, w_{i} \neq 0} \nu_{i} B_{i}^{n}(t)}{\sum_{i=0}^{n} w_{i} B_{i}^{n}(t)}
$$

w którym zamiast punktów $p_{i}$, takich że $w_{i}=0$, występują wektory kontrolne $\nu_{i} ; B_{i}^{n}(t)$ oznaczają wielomiany Bernsteina stopnia $n$ i są zdefiniowane nastepująco

$$
B_{i}^{n}(t)=\left(\begin{array}{c}
n \\
i
\end{array}\right) t^{i}(1-t)^{n-1} \quad i=0, \ldots, n
$$


Wybór sposobu modelowania krzywej określonej wzorem (3.4) lub modyfikowanym (3.5) skutkuje odwzorowaniem w postaci krzywej jednorodnej, której punkty kontrolne spełniają zależności

$$
p_{i}=\left\{\begin{array}{lll}
{\left[w_{i} p_{i}, w_{i}\right]^{\mathrm{T}}} & \text { dla } & w_{i} \neq 0 \\
{\left[\nu_{i}, 0\right]^{\mathrm{T}}} & \text { dla } & w_{i}=0
\end{array}\right.
$$

Łamana kontrolna wymiernej krzywej Béziera (rys. 14) jest obrazem krzywej jednorodnej w rzucie na płaszczyznę roboczego układu współrzędnych dowolnego kształtu opisującego budowany model geometryczny.

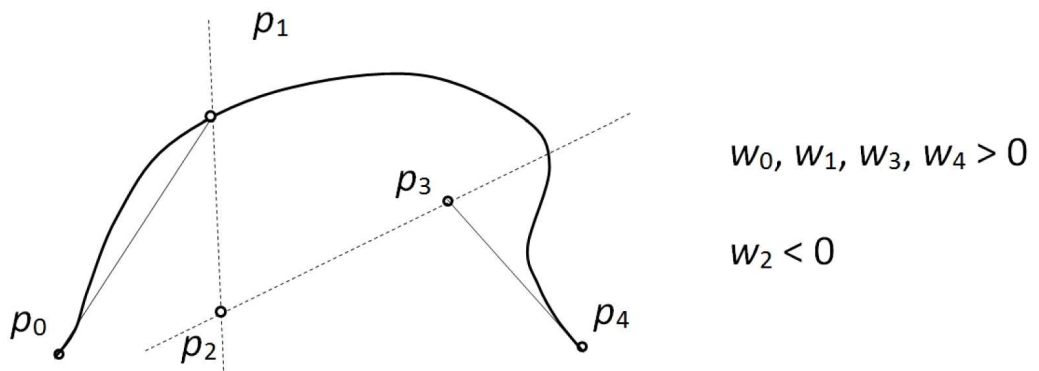

Rys. 14. Łamana kontrolna krzywej wymiernej z wagami o różnych znakach

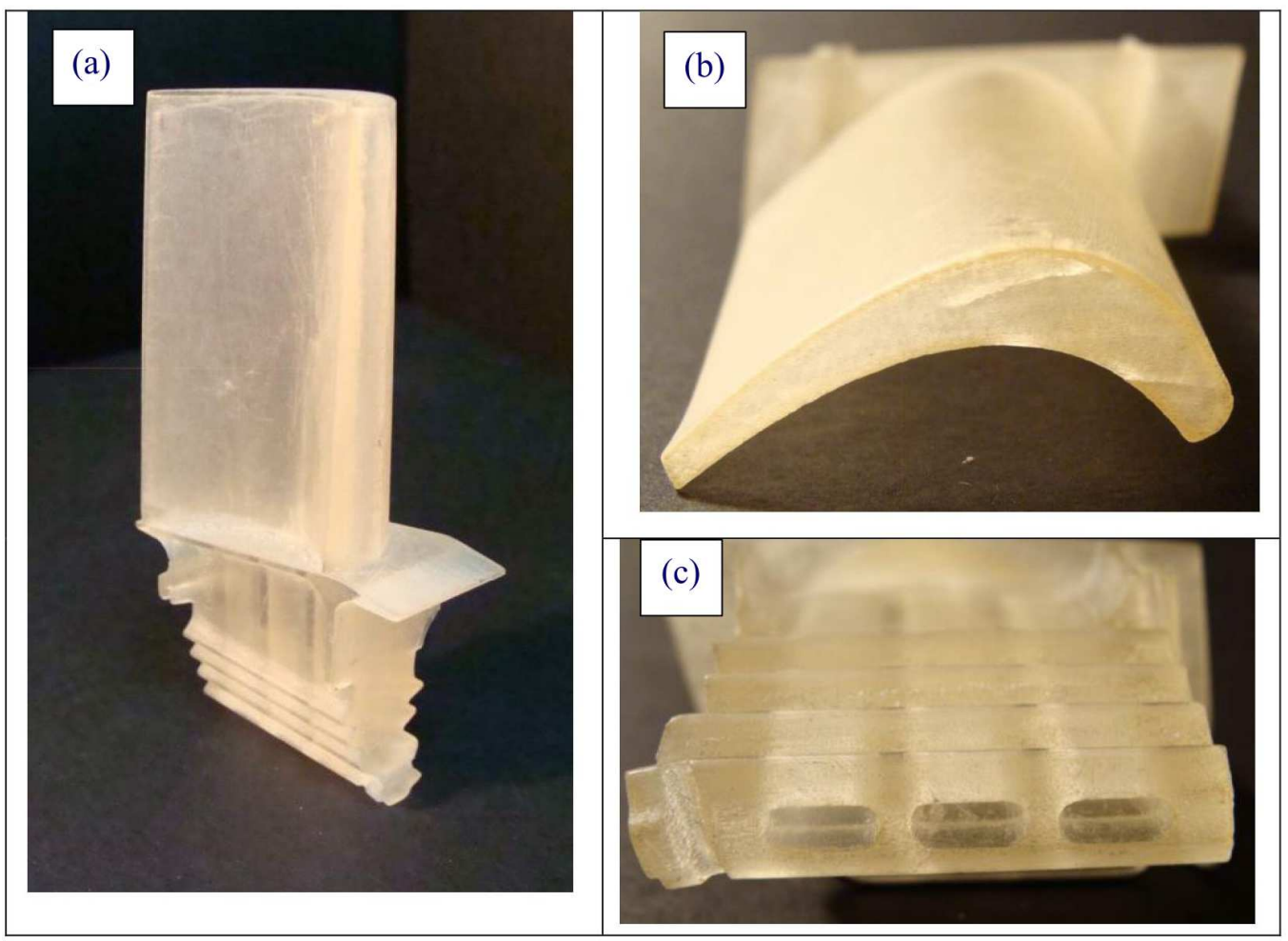

Rys. 15. Wydrukowany model łopatki turbiny wysokiego ciśnienia silnika RD-33: (a) widok całej łopatki, (b) profil końcowy łopatki, (c) zamek jodełkowy łopatki z kanałami chłodzaccymi

Do przeprowadzenia optymalizacji doboru punktów dla krzywej odwzorowujacej profil aerodynamiczny opracowano program w języku GRIP dla systemu Siemens NX, którego kluczowe fragmenty zamieszczono w artykule [8].

W wyniku realizacji programu otrzymano zbiory punktów odwzorowujacych poszukiwaną krzywiznę profili (rys. 13b) na ściśle zdefiniowanych wysokościach pióra łopatki. Umożliwiło to zbudowanie modelu łopatki (rys. 13c). Końcowym sprawdzianem zbudowanego modelu był jego wydruk w 3D (rys. 15). 


\section{Wnioski}

Celem prowadzonej pracy było rozpoznanie układu geometrycznego i zbudowanie modelu łopatki turbiny wysokiego ciśnienia silnika RD-33 eksploatowanego w Siłach Powietrznych RP. Ma to służyć rozpoznaniu charakterystyk aerodynamicznych samej łopatki oraz palisady turbiny.

Zbudowano geometryczny model turbiny wysokiego ciśnienia przy wykorzystaniu inżynierii odwrotnej i procedur optymalizacyjnych. Charakteryzował się on dużą liczbą zmiennych. Do rozwiązania postawionego problemu należało się posługiwać wiedzą z zakresu metod kombinatoryczno-cyklicznych budowy wirtualnych modeli, warunków pracy i współpracy podzespołów lotniczych silników turbinowych, w tym problemu dotyczących ich charakterystyk oraz zagadnień przepływowych. Uzyskany model będzie podstawą dalszych badań. Mają one dostarczyć informacji o charakterystykach przepływowych, między innymi o polach prędkości przepływu w kanale międzyłopatkowym. Przykładowy uzyskany wynik rozkładu liczby Macha został przedstawiony na rys. 16 .

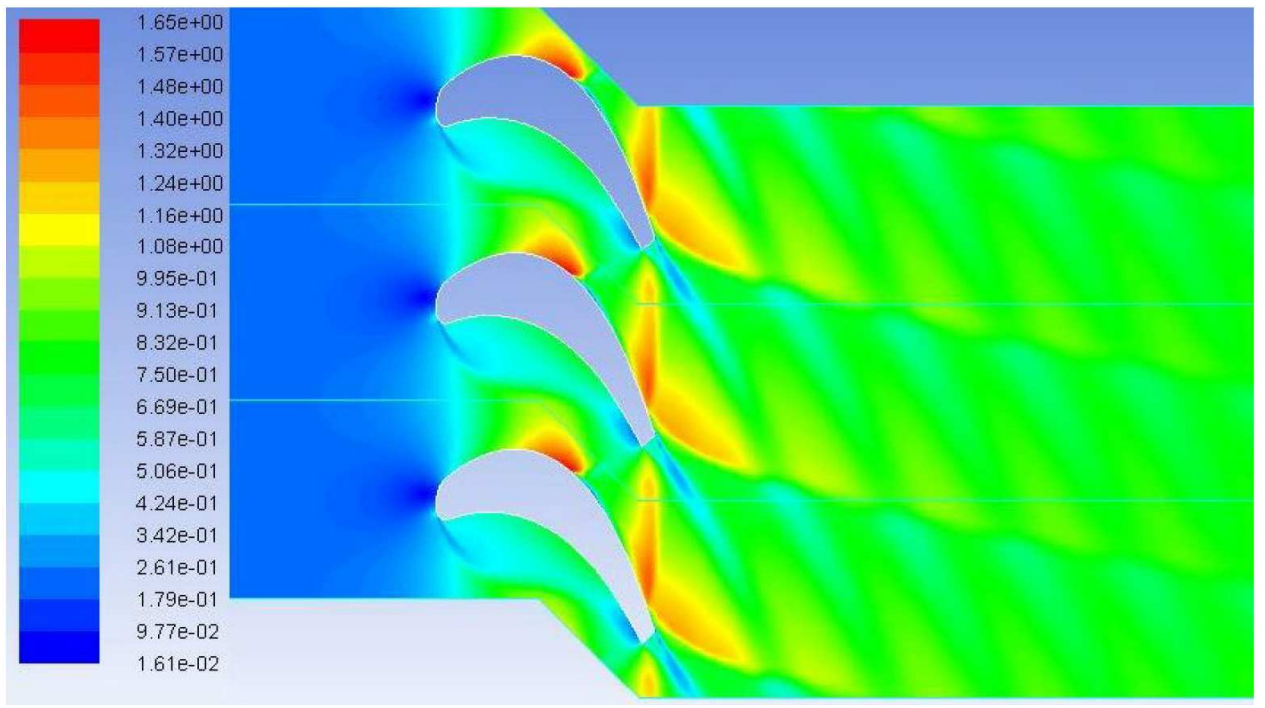

Rys. 16. Rozkład liczby Macha w palisadzie turbiny przy pracy silnika na zakresie przelotowym

Przeprowadzona analiza charakterystyk turbin ma umożliwić w kolejnym etapie badań ocenę możliwości doskonalenia samego układu konstrukcyjnego turbiny. Informacje te moga posłużyć do poprawy eksploatacji i żywotności silnika, przez korekcję zakresów pracy silnika. Uzyskany model oraz wyniki autorzy zamierzają wykorzystać również do obliczeń zmęczeniowych tego zespołu silnika, ponieważ problem uszkodzeń zmęczeniowych coraz częściej pojawia się podczas eksploatacji turbiny silnika RD-33.

\section{Bibliografia}

1. AGARD Lecture Series No.83, Modern Prediction Methods for Turbomachine Performance, Munich-London, 1976

2. Balicki W., Chachurski R., Kozakiewicz A., Geowacki P., Godzimirski J., Kawalec K., Pagowski Z., Rowiński A., Szczeciński J., Szczeciński S., Lotnicze silniki turbinowe, konstrukcja-eksploatacja-diagnostyka, Część I, Wydawnictwo Naukowe Instytutu Lotnictwa, Warszawa, 2010

3. Balicki W., Chachurski R., Kozakiewicz A., Geowacki P., Godzimirski J., Kawaled K., Pagowski Z., Rowiński A., Szczeciński J., Szczeciński S., Lotnicze silniki turbinowe, 
konstrukcja-eksploatacja-diagnostyka, Część II, Wydawnictwo Naukowe Instytutu Lotnictwa, Warszawa, 2012

4. Koff B.L., Gas turbine technology evolution: a designer's perspective, Journal of Propulsion and Power, 20, 4, July-August, 2004

5. Beyene A., Miller A., Krytyczna ocena metod określania strat w turbinowych palisadach profili, Biuletyn Informacyjny Techniki Cieplnej Politechniki Warszawskiej, 68, Warszawa, 1986

6. Lakshminarayana B., Fluid Dynamics and Heat Transfer of Turbomachinery, John Wiley \& Sons, Inc., New York, 1996

7. KACHEL S., Application of the GRIP CAD/CAM/CAE Language for the Reverse Engineering Parametric Modelling Method of the Aviation Structures, RRDPAE 2008, ISSN: 1425-2104 Volume 2008

8. Kachel S., Kozakiewicz A., Practical usage of CAD/CAM/CAE GRIP language system aircraft parametric modeling with reverse engineering methods, Biuletyn WAT, LIX, 3(659), 171-200, Warszawa, 2010

9. Kachel S., Kozakiewicz A., Łącki T., Olejnik A., Zastosowanie inżynierii odwrotnej do procesu odtwarzania geometrii układu wlotowego silnika RD-33 w samolocie MiG-29, Prace Instytutu Lotnictwa, 213, 66-84, Warszawa, 2011

10. Hazandżan P.K., Teorija awiacionnyh dwigatelej. Teorija lopatocznyh maszin, Maszinostroenie. Moskwa, 1995

11. Kozakiewicz A., Analiza porównawcza osiągów turbinowych silników odrzutowych samolotów bojowych obecnie użytkowanych w RP, Biuletyn WAT, LVIII, 2, Warszawa, 2009

12. KozAKIEWICZ A., Estymacja punktu pracy w celu optymalizacji geometrii elementów palisady sprężarki, Wydawnictwo Politechniki Poznańskiej, Poznań, 2013

13. Panchenko Y., Moustapha H., Mah S., Patel K., Dowhan M.J., Hall D., Preliminary multi-disciplinary optimization in turbomachinery design, RTO AVT Symposium on „Reduction of Military Vehicle Acquisition Time and Cost through Advanced Modelling and Virtual Simulation", RTO-MP-089, 57-1-57-22, Paris, 2002

14. Sooriyakumaran C., Experimental Study of Profile Losses in Three Transonic Turbine Cascades, Carleton University, Ottawa, Ontario, 2014

15. Ziętarski S., Kachel S., Kozakiewicz A., A new approach to identification and optimization of airfoils by using the combinatorial-cyclic method, ICASS Australia 2012, ID 883, ICAS2012-P2.24

16. Ziętarski S., Kachel S., Kozakiewicz A., Wrzesień S., The Combinatorial-Cyclic method of Optimization (CCOpt) in a scaled or full sized prototyping and virtual prototyping, 4th International Conference on Engineering Optimization EngOpt 2014, Instiuto Superiror Tecnico Lisbon, Portugal, 2014

\section{Design of high-pressure turbine blade model in jet engines}

This article is dedicated to design of a high-pressure turbine blade model of a jet engine. We present an idea of the design process for the turbine blade as well as relevant turbine parameters which were included in the analysis of turbine characteristics. The presented characteristics concern changes of main parameters of the turbine such as mass flow rate, unit work, efficiency, load or pressure ratio in comparison with operational parameters. For the purposes of this paper, the process of creating a blade model was analysed based on reverse engineering and parameterization of the model. An algorithm for creating the parametric model was built in GRIP language for Siemens NX system. The most important advantages of a parametric model were discussed, including a mathematical equivalent of choosing a variant of the virtual object modelling process. The result in the form of a $3 \mathrm{D}$ blade printout is presented. The obtained model will be the baseline for further analysis of aerodynamic characteristics concerning a singular turbine blade as well as a cascade of turbine blades. 